\title{
Article
}

\section{Practices and Perspectives of College Instructors on Addressing Religious Beliefs When Teaching Evolution}

\author{
M. Elizabeth Barnes and Sara E. Brownell*
}

Biology Education Research Lab, School of Life Sciences, Arizona State University, Tempe, AZ 85287-4501

Submitted November 29, 2015; Revised February 17, 2016; Accepted February 17, 2016

Monitoring Editor: Jeff Schinske

Evolution is a core concept of biology, and yet many college biology students do not accept evolution because of their religious beliefs. However, we do not currently know how instructors perceive their role in helping students accept evolution or how they address the perceived conflict between religion and evolution when they teach evolution. This study explores instructor practices and beliefs related to mitigating students' perceived conflict between religion and evolution. Interviews with 32 instructors revealed that many instructors do not believe it is their goal to help students accept evolution and that most instructors do not address the perceived conflict between religion and evolution. Instructors cited many barriers to discussing religion in the context of evolution in their classes, most notably the instructors' own personal beliefs that religion and evolution may be incompatible. These data are exploratory and are intended to stimulate a series of questions about how we as college biology instructors teach evolution.

\begin{abstract}
Scientists also must realize that the presentation of science, though necessary, is not sufficient in itself. For topics such as evolution or climate change, where there may be religiously-based opposition, "mere" science will not be persuasive on its own.
\end{abstract}

Eugenie C. Scott, former executive director of the National Center for Science Education, 2013

\section{INTRODUCTION}

Evolution has been defined as one of the core concepts of biology (American Association for the Advancement of Science [AAAS], 2011; Brownell et al., 2014) and is often referenced as the grand unifying theory of biology (Dobzhansky,

CBE Life Sci Educ June 1, 2016 15:ar18

DOI:10.1187/cbe.15-11-0243

*Address correspondence to: Sara E. Brownell (Sara.brownell@asu .edu).

(C) 2016 M. E. Barnes and S. E. Brownell. CBE-Life Sciences Education (c) 2016 The American Society for Cell Biology. This article is distributed by The American Society for Cell Biology under license from the author(s). It is available to the public under an Attribution-Noncommercial-Share Alike 3.0 Unported Creative Commons License (http:/ / creativecommons.org/licenses/by-nc-sa/3.0).

"ASCB ${ }^{\circledR}$ " and "The American Society for Cell Biology ${ }^{\circledR}$ " are registered trademarks of The American Society for Cell Biology.
1973; Mayr, 1982; Gould, 2002; Heddy and Nadelson, 2012). However, a significant portion of the population rejects evolutionary theory. According to a 2014 Gallup poll, $42 \%$ of Americans reported that they believed that humans arrived on Earth in their present form (Newport, 2014). Even among students in introductory biology classes, rejection rates of evolution can reach up to 50\% (Rice et al., 2010).

Multiple agencies and evolution education researchers have indicated that students' acceptance of evolution is important. The National Academy of Sciences (NAS) and the AAAS have issued several documents that highlight the importance of a scientifically literate society that is equipped to make policy decisions of the future (AAAS, 2011; Singer et al., 2012). Applying evolutionary concepts to solve problems is one component of being a scientifically literate citizen (NAS, 1998, 2008), but this is unlikely to happen if a person rejects evolution. (Sinatra et al., 2008). More than 165 studies from evolution education researchers have focused on student acceptance of evolution, and leaders in this field have proposed that student acceptance is an important aim of evolution education (Cobern, 1994; Alters, 1997; Sinatra et al., 2008; Nehm et al., 2009; Rutledge and Sadler, 2011; Nadelson and Southerland, 2012). If the consensus of the scientific community is to help students become scientifically literate and to incorporate evolution into their scientific thinking, policy making, and voting decisions (NAS, 2008; AAAS, 2011), then it may be important for instructors to help 
students accept evolution. However, we currently do not know how college instructors perceive their role in helping students accept evolution.

In this paper, we define student acceptance of evolution as the extent to which a student accepts that evolution is the best scientific explanation for the diversity of life on Earth, which is in accordance with definitions from national documents (NAS, 1998, 2008). We define student understanding of evolution as the extent to which a student has an accurate conception of the tenets and processes of evolutionary theory. While we acknowledge that student understanding of evolution is important, we delineate this as a construct separate from acceptance, and it is not a focus of this paper.

Students who understand but do not accept evolution may not apply evolutionary thinking when making public decisions related to biology, such as wildlife and disease management, which can affect both biodiversity and global human health. Voters who do not incorporate deep time and the coevolution of species into their thinking may not be able to fully appreciate the complex interconnectedness of all organisms on Earth and thus the extent to which the extinction of one species, or the pollution of one environment, might affect global biodiversity. Also, accepting that humans have evolved from other animals highlights the shared cognitive processes and basic mental capacities of all animals, such as the capacity to feel pain and fear, which could affect voting decisions on animal welfare (Rachels, 1990; Singer et al., 2012). Finally, researchers in evolutionary medicine have suggested that physicians need to account for the evolutionary history of humans to adequately understand and treat diseases such as obesity, heart disease, and mental illness, some of the most prevalent ailments that affect humans today (Nesse, 1996; Nesse et al., 2010). If instructors only focus on student understanding of evolution and avoid addressing student acceptance, then the desired outcomes of science education may be diminished.

\section{Factors Influencing Student Acceptance of Evolution}

Researchers have identified several factors that influence student acceptance of evolution. Acceptance of evolution has been positively correlated with higher educational levels (Heddy and Nadelson, 2012; Rissler et al., 2014) except in cases of biblical literalists, who become less accepting of evolution with higher levels of education (Baker, 2013). Researchers have found that the level of hypothetico-deductive reasoning of high school students is positively related to student acceptance of evolution (Lawson and Worsnop, 1992) and the level of intuitive reasoning of college students is negatively related to their acceptance of evolution (Gervais, 2015). This is in line with work that has identified cognitive constraints that make the idea of evolution feel intuitively false to the human mind, just as the idea of a spherical Earth is initially unintuitive to most children (Evans, 2001; Sinatra et al., 2008). So if a student has more of an intuitive thinking style than an analytical reasoning style, it may be difficult for him or her to override initial intuitions about the improbability of evolution. Other factors that positively impact an individual's acceptance of evolution include a higher socioeconomic status (Heddy and Nadelson, 2013) and trust in science and scientists (Nadelson and Hardy, 2015)
However, of the many factors that have been shown to influence acceptance of evolution, religious commitment is the strongest. Most researchers recognize that it is Judeo-Christian and Muslim belief systems that are most likely to conflict with evolution (Scott, 2005). If a person's commitment to religion is high, then his or her acceptance of evolution is predicted to be low regardless of other factors that have been shown to be related to acceptance (Sinclair et al., 1997; Alters and Nelson, 2002; Eve et al., 2010; Allmon, 2011; Southerland and Scharmann, 2013; Rissler et al., 2014; Rice et al., 2015). The vast majority of individuals in the United States report being religious (Pew Research Center, 2015) and more than half of the students in U.S. biology classes report being religious (Ingram and Nelson, 2006; K.C. Cooper, personal communication), making religious belief ${ }^{1}$ a prevalent potential barrier to student acceptance of evolution. Further, similar to the general public, it has been shown that students struggle with a perceived conflict between evolution and their religious beliefs, and some students may resist learning about evolution (Sinatra et al., 2003).

Religiosity, the extent to which one is committed to and practices religion, has a minimal effect on one's understanding of evolution (Ingram and Nelson, 2006; Rissler et al., 2014), and this might lead instructors to conclude they do not need to address religious concerns when teaching evolutionary theory. However, studies have shown that, if a student has an accurate understanding of evolution, this does not necessarily mean he or she is more likely to accept evolution (Sinatra et al., 2003; Lloyd-Strovas and Bernal, 2012).

\section{A Potential Solution: Reducing Students' Perceived Conflict between Religion and Evolution}

To reduce student resistance to learning evolution, researchers have proposed that we need to diminish the perceived conflict between religion and evolution in biology classes. Smith has urged instructors to discuss with students how the nature of science implies that evolution and religion do not have to be in conflict (Smith, 1994). In 2013, Southerland and Scharmann posited that teaching the bounded nature of science in relation to religion can help students be more open to subjects that generally conflict with religious ideas. They argue that engaging students' religious beliefs might be the most important factor to consider when teaching scientific subjects that relate to human origins (Southerland and Scharmann, 2013). These suggestions are supported by an emerging empirical literature.

Several studies support the assertion that discussions of religion in college science classrooms can help students be more open to evolution. In an interview study done in Lebanon, researchers found that Christian and Muslim college students reported an appreciation for discussions about the relationship between evolution and religion. The authors argued that students' experience learning evolutionary theory is likely

${ }^{1}$ The extent to which religious belief matters is how salient the religious belief is to a student and which religious belief the student has. There are some religions that have put forward statements that indicate that they endorse evolution, whereas others have officially taken an antagonistic stance toward evolution. Throughout this study, we referred to student religious beliefs broadly, without disaggregating it into specific denominations/sects, because instructors are unlikely to know specific student religious beliefs. 
to be enhanced by discussions of the nature of science and students' values and beliefs in relation to scientific knowledge (Dagher and BouJaoude, 1997). An interview study in a non-majors astronomy class in the United States with college students of different religious beliefs demonstrated that having open discussions about the relationship between religion and science increased students' positive views of science and evolution (Brickhouse et al., 2000).

Helping students construct bridges between their religious beliefs and evolution may also help students accept evolution. In a case study done in Canada with two high school physics students over a period of $2 \mathrm{yr}$, researchers explored the interaction between students' personal religious beliefs and their learning of controversial topics in class. They found that the two students used both rational and social discourses to evaluate scientific claims, yet still came to different conclusions about whether or not they believed them. On the basis of their examination of the students' discourse, the authors concluded that educators may have to help students construct mediating concepts between their religious worldviews and potentially controversial concepts in science for students to accept those concepts (Roth, 1997).

In fact, empirical studies are beginning to support Roth's conclusion. Manwaring et al. (2015) found that by showing LDS (Mormon) college students that their denomination had an official neutral stance on evolution, they were able to increase those students' acceptance of evolution. In a study done with college biology majors, the number of students who perceived conflict between evolution and religion was reduced by half after a 2-wk module on evolution in which the instructors highlighted the compatibility between religion and evolution (Barnes et al., in press, 2017). Thus, this literature indicates that students can benefit from instruction in which their religious beliefs are acknowledged by instructors and in which instructors discuss how religion and evolution can be compatible.

Additionally, the availability of religious scientist role models has been shown to affect student acceptance of evolution. For instance, Winslow et al. (2011) found that a significant factor for Christian biology majors to accept evolution was these students' interactions with their religious biology professors who reassured them there need not be a conflict between religion and evolution. Thus, providing students with examples of biologists who have values similar to their own could facilitate greater acceptance of evolution among students.

\section{Potential Barriers to Reducing Students' Perceived Conflict between Religion and Evolution}

Despite calls for acknowledging students' religious beliefs when teaching evolution (Smith, 1994; Southerland and Scharmann, 2013) and preliminary evidence that engaging with students' religious beliefs may be effective for helping students accept evolution (Roth, 1997; Wiles and Alters, 2011; Winslow et al., 2011; Barnes et al., in press, 2017), we know little about college biology instructors' practices related to addressing religious beliefs when teaching evolution (Dagher and BouJaoude, 1997). We suspect that biology instructors may perceive barriers to addressing religious beliefs in the classroom for the following reasons.
First, educators' lack of experience in teaching the nature of science in relation to religion may cause them to feel unprepared to engage in these discussions about evolution and religion (Southerland and Scharmann, 2013). Second, biology educators may not want to discuss religion, because their own belief systems may be different from their students' belief systems. Many biologists do not hold religious beliefs: $22 \%$ of biologists report a belief in God in contrast to $77 \%$ of the public who hold religious beliefs (Ecklund and Scheitle, 2007; Pew Research Center, 2015); evolutionary biologists are even less religious, with only $4.7 \%$ reporting belief in any existence of the supernatural (Graffin and Provine, 2007). Third, there is a long history of attempts by certain religious groups to legislate the teaching of creationism as a valid alternative to the theory of evolution. Over the past $100 \mathrm{yr}$, religious groups have repeatedly attempted to either prevent educators from teaching evolution or demand the teaching of creationism as an alternative theory (Numbers, 2006). While much of this legislation has centered on K-12 instruction, it may cause college-level biology instructors to be wary of discussions of religion in the classroom, even when these discussions are not about teaching religious doctrine but about acknowledging religion as a part of students' social identities. Also, there is potential disagreement about whether it should be an educator's goal to help students both understand and accept evolution (Alters, 1997; Sinatra et al., 2003; Shtulman and Calabi, 2008; Smith, 2009; Nadelson and Southerland, 2010). A biology educator might perceive his or her duty to be to help students to understand evolution but that helping students accept evolution would be beyond his or her job as a science educator. Finally, a biology instructor may perceive that a lack of discussion about religion will help to avoid potential conflicts in the classroom. However, a recent study has shown that presenting evolution without making reference to religion can alienate religious students (Hermann, 2012). In this study, done with high school students in AP science courses, students expressed dissatisfaction with instructors' neglect of the relationship between evolution and religion in class. If biology instructors present the science of evolution but ignore the religious sociocultural context surrounding evolution, then prior literature indicates that student acceptance of evolution is unlikely to change (Scott, 2014).

\section{The Current Study}

Currently, we do not know the reasons why instructors decide to discuss or not discuss religion in relation to evolution and what barriers they perceive to discussing religion when teaching evolution. In this paper, we report the results of an exploratory interview study of 32 college biology instructors who teach about evolution in undergraduate biology classes in Arizona. While there are many studies in the literature that explore student acceptance of evolution (Dagher and BouJaoude, 1997; Ingram and Nelson, 2006; Wiles and Alters, 2011; Hermann, 2012; Rissler et al., 2014), this study fills a void in the literature on instructor perspectives of their instructional practices related to student acceptance of evolution. We set out to investigate the following research questions: 
1. Do college biology instructors who teach evolution have a goal to promote student acceptance of evolution? Why or why not?

2. To what extent do college biology instructors who teach evolution discuss religion in the classroom? Why do they choose to discuss or not discuss religion?

3. Do college biology instructors who teach evolution utilize instructional practices that align with suggestions in the literature for increasing student acceptance of evolution? Why or why not?

4. What barriers hinder instructors from engaging with students' religious beliefs when teaching evolution?

\section{METHODS}

\section{Instructor Recruitment}

We recruited a convenience sample of instructors who teach evolution at public institutions of higher education in Arizona. We recruited from 10 community colleges in Maricopa County, which is the largest community college network in Arizona, and three public R1 institutions in Arizona. Collectively, these institutions serve a diverse demographic of students and a range of geographic locations. The Maricopa Community College network is composed of $\sim 50 \%$ ethnic minority students and $40 \%$ nontraditional students (over the age of 22), while the universities in Arizona are composed of 35-40\% minorities and span northern, central, and southern Arizona (Arizona State University, 2013; Forbes, 2014; Maricopa Community Colleges, 2012; University of Arizona, 2014). We chose to interview instructors from public institutions, because private institutions could have special interests that influence instructor practices, including how evolution is taught. We specifically chose to recruit from a subset of 2 -yr colleges, because $\sim 70 \%$ of students in public colleges in Arizona attend 2-yr colleges (National Center for Education Statistics, 2013). We limited our sampling to Arizona public institutions of higher education. We did this to limit the data collection to a realistic number of individuals and to keep constant different political and religious contexts that may lead to different instructional practices in different states.

Instructors of college biology with full-time positions at these institutions were identified through their online institutional profiles and sent individual emails. Instructors were then sent a reminder email approximately 2-wk later if they had not responded. We limited our study population to instructors with full-time positions, because we thought that the controversial nature of discussing religion in a classroom might limit the openness of instructors who do not have secure positions. Because full-time faculty have greater job security, we thought they would be more open about their beliefs and practices, so we included tenured and nontenured full-time faculty. Our recruitment email asked instructors whether they would participate in a 30- to 60-min interview exploring their perspectives on how students might experience conflict between their worldviews and evolution and how they, as instructors, might address this in their classrooms. Out of the instructors who responded to the email, we included only interviews with instructors who taught an evolution lesson to undergraduates within the past $7 \mathrm{yr}$. This ensured that the instructors had been teaching evolution after the publication of national documents that outlined the potential compatibility between religion and evolution (NAS, 1998, 2008).

\section{Data Collection}

Thirty-two semistructured interviews were conducted by M.E.B. between Spring 2014 and Fall 2015. The set of questions that guided the interview can be found in Table 1. Interviews lasted from 15 to $75 \mathrm{~min}$, averaged $35 \mathrm{~min}$, and were audio recorded.

A survey was administered to all instructors immediately after the interview to record demographic information,

Table 1. Question checklist that was used during interviews with instructors

Experience teaching evolution

Perception of student rejection rates

Goal when teaching evolution

Use of specific strategies when discussing religion and evolution

Perception of what it means to "accept evolution"

Personal experiences learning evolution
How many years have you been teaching evolution to undergraduates?

Are there specific strategies you use to teach evolution? What are they?

Do you have any strategies related to religion when you teach evolution? What are they?

Do you mention religion at all in your class? How?

Have you ever been challenged by a student in class about evolution? If so, describe your experience.

Would you be willing to guess what percent of students in your class reject evolution?

Have you ever asked?

As a biology educator do you think it is part of your job or goal to help students become more comfortable with and accept evolution? Or do you only aim for students to understand evolution? Why?

Do you discuss the spectrum of viewpoints that exist about the relationship between religion and evolution? If no, why not? Would you?

Do you discuss that evolution does not mean atheism/ evolution is compatible with religion? If no, why not? Would you?

Do you provide students with religious scientist role models who accept evolution? If no, why not? Would you?

What is "acceptance of evolution"?

If a student says they accept common ancestry and natural selection but they believe God started or planned evolution, does that student accept or reject evolution? Why or why not?

Did you experience any worldview conflict with evolution when you learned about it? Any other time? Why or why not? 
academic credentials, experience teaching evolution to undergraduates, childhood and current religious affiliation, and perceptions of whether there is a role for God $/ \operatorname{god}(\mathrm{s})^{2}$ in evolution (Supplemental Material). We asked instructors what role they believe God may have played in evolution and had three evolutionary biologists review the question for accuracy and interpretation. We asked instructors to choose what came closest to their personal beliefs: 1) Human beings have evolved over billions of years from older life-forms, and God guided this process. 2) Human beings have evolved over billions of years from older lifeforms, and God started this process but did not intervene after. 3) Human beings have evolved over billions of years from older life-forms, and God was not involved in this process. 4) Human beings have evolved over billions of years from older life-forms, and I do not know whether or not God had anything to do with this process. 5) God created human beings more or less in their present form. We decided to administer these questions via a survey after the interview, because we did not want the participants to feel as though the interview was about their personal religious beliefs rather than their instructional practices, which could make them uncomfortable.

All research was approved by the Arizona State University's Institutional Review Board (protocol 00000631).

\section{Data Analysis}

Interviews were initially transcribed and coded by M.E.B. using a combination of content analysis and grounded theory. She used content analysis to identify predetermined themes that the research team was interested in exploring before the data collection (Krippendorff, 2012), and she used grounded theory to identify additional themes from the interview transcripts that emerged after the data collection (Glaser and Strauss, 2009). For instance, when exploring instructor practices, she used content analysis to explore the predetermined theme "provides students with examples of religious scientist role models," but she also discovered new instructor practices via grounded theory, such as the theme "presents evolution in a way that seems incompatible with religion."

The analysis was an iterative process in that themes and categories were molded and transformed with each additional reading of the transcripts. Categories consist of different types of instructor perspectives and experiences, and multiple categories usually fit under one theme. For instance, "instructors provide students with religious scientist role models" and "instructors discuss the spectrum of viewpoints about religion and evolution" would be categories within the theme "instructors address religion in class." Most themes and categories were specific to one interview question. For instance, the theme "goals of evolution instructors" and the category "instructor does not consider acceptance of evolution as part of their instructional goal" consisted mostly of quotes from responses to the interview question in which M.E.B. asked instructors about their goals

\footnotetext{
${ }^{2}$ We use the term God/god(s) to be as inclusive as possible, since some religions prefer capitalization and some recognize multiple deities. We acknowledge that some religions do not use the word "God," "god," or "gods" to describe a higher power, so we encourage readers to interpret this term broadly.
}

when teaching evolution. A theme was created from each interview question, and then categories emerged from instructor responses to those questions. Constant comparison methods (Glesne and Peshkin, 1992) were used throughout the analysis. That is, quotes that were assigned to specific themes and categories were gathered together and compared with one another throughout the iterative process of qualitative analysis. This constant comparison of quotes was meant to ensure that the description of the theme and category adequately represented all quotes within the same group and that the quotes were not different enough from one another to deem a separate category or theme.

\section{RESULTS}

\section{Interrater Reliability}

After M.E.B. completed the analysis of the data, she created a coding rubric. The coding rubric consisted of detailed descriptions of each theme and category that was established in the analysis. The rubric also included instructions on how to code the transcripts, which was reflective of M.E.B.'s process when she did her final round of coding. To establish interrater reliability, a second researcher used the codebook without the help of M.E.B. to blindly code $\sim 10 \%$ of the statements originally coded by M.E.B. After the second researcher coded the statements, M.E.B. labeled each statement based on whether the second researcher applied the same code to the statement as M.E.B.

The independent codes from both researchers agreed $91 \%$ of the time. However, reporting percent agreement for interrater reliability may inflate agreement rates because percent agreement does not take into account agreement that would occur by chance alone (Hallgren, 2012). Therefore, in addition to percent agreement we also used a kappa statistic to measure the observed level of agreement among raters and control for agreement that would happen by chance. Cohen's kappa was calculated in SPSS 21 for each coded statement and then averaged. Our average Cohen's kappa was 0.83 , which indicates very high agreement (Landis and Koch, 1977). Some researchers have questioned the utility of interrater reliability in qualitative studies using unstructured interviews, because this might compromise the richness and depth of the analysis and results (Morse, 1997). However, this is less of a concern with research designs such as ours, in which the interview questions remain the same for all interviews and are asked in the same order in each interview.

\section{Response Rates and Demographics}

Of the 229 instructors emailed for recruitment, 32 completed interviews that were used in our analyses ( $\mathrm{R} 1$ universities $=$ $19 / 149$ [13\%], community colleges $=13 / 80$ [16\%]) for a total response rate of $14 \%$ (see the Limitations section for a discussion on low response rates). There were 21 male participants (66\%) and 11 female participants (34\%). Twenty-nine out of $32(90 \%)$ of the instructors were teaching a biology course in which evolution was one of many topics, and 5/32 $(16 \%)$ of the instructors were teaching a course in which evolution was the primary topic (some instructors taught both types of courses, so the percentages do not add up to 100). 
Table 2. Instructor survey responses to demographic questions and other survey questions as well as their position at an R1 institution or community college

\begin{tabular}{|c|c|c|c|c|c|c|c|c|}
\hline Pseudonym & Gender & $\begin{array}{l}\text { Current religious } \\
\text { identification }\end{array}$ & $\begin{array}{l}\text { Family religion } \\
\text { in childhood }\end{array}$ & $\begin{array}{l}\text { Highest } \\
\text { degree }\end{array}$ & $\begin{array}{c}\text { Years teaching } \\
\text { undergraduate } \\
\text { biology }\end{array}$ & $\begin{array}{l}\text { Level of } \\
\text { self-reported } \\
\text { experience } \\
\text { teaching } \\
\text { evolution }\end{array}$ & $\begin{array}{l}\text { Personal belief about } \\
\text { God and evolution }{ }^{\mathrm{a}}\end{array}$ & $\begin{array}{l}\mathrm{R} 1 \text { or } \mathrm{CC} \\
\text { instructor }^{\mathrm{b}}\end{array}$ \\
\hline Neil & Male & Agnostic & Jewish & $\mathrm{PhD}$ & 28 & Moderate & No God involvement & R1 \\
\hline Albert & Male & Agnostic & Catholic & $\mathrm{PhD}$ & 12 & High & $\begin{array}{l}\text { Unsure of God } \\
\text { involvement }\end{array}$ & R1 \\
\hline Martin & Male & Agnostic & Protestant & $\mathrm{PhD}$ & 44 & High & No God involvement & R1 \\
\hline Janet & Female & Agnostic & Catholic & $\mathrm{PhD}$ & 20 & Moderate & No God involvement & $\mathrm{CC}$ \\
\hline Chester & Male & Agnostic & Protestant & $\mathrm{PhD}$ & 22 & High & No God involvement & $\mathrm{CC}$ \\
\hline Frank & Male & Atheist & Catholic & $\mathrm{PhD}$ & 7 & Moderate & No God involvement & R1 \\
\hline Edward & Male & Atheist & Protestant & $\mathrm{PhD}$ & 24 & Moderate & No God involvement & R1 \\
\hline Marie & Female & Atheist & Protestant & $\mathrm{PhD}$ & 23 & Low & No God involvement & R1 \\
\hline John & Male & Atheist & $\begin{array}{l}\text { Atheist/ } \\
\text { Catholic }\end{array}$ & $\mathrm{PhD}$ & 30 & Low & No God involvement & R1 \\
\hline Anthony & Male & Atheist & Catholic & $\mathrm{PhD}$ & 25 & High & No God involvement & R1 \\
\hline Rose & Female & Atheist & Jewish & $\mathrm{PhD}$ & 32 & High & $\begin{array}{l}\text { Unsure of God } \\
\text { involvement }\end{array}$ & R1 \\
\hline Rachel & Female & Atheist & $\begin{array}{l}\text { Jewish/ } \\
\text { Agnostic }\end{array}$ & $\mathrm{PhD}$ & 11 & High & No God involvement & $\mathrm{R} 1$ \\
\hline Lynn & Female & Atheist & Protestant & $\mathrm{PhD}$ & 10 & Moderate & No God involvement & R1 \\
\hline Victoria & Female & Atheist & Protestant & $\mathrm{PhD}$ & 10 & High & No God involvement & $\mathrm{CC}$ \\
\hline Craig & Male & Atheist & Atheist & Master's & 11 & High & No God involvement & $\mathrm{CC}$ \\
\hline Irene & Female & Atheist & $\begin{array}{r}\text { Protestant/ } \\
\text { Atheist }\end{array}$ & Master's & 43 & High & No God involvement & $\mathrm{CC}$ \\
\hline Emma & Female & Atheist & Catholic & $\mathrm{PhD}$ & 20 & Low & No God involvement & $\mathrm{CC}$ \\
\hline Danny & Male & Atheist & Protestant & $\mathrm{PhD}$ & 19 & High & No God involvement & $\mathrm{CC}$ \\
\hline Theodore & Male & Atheist & Catholic & $\mathrm{PhD}$ & 29 & High & No God involvement & $\mathrm{CC}$ \\
\hline Charles & Male & $\begin{array}{l}\text { Atheist/ } \\
\text { cultural Jew }\end{array}$ & Jewish & $\mathrm{PhD}$ & 11 & High & No God involvement & R1 \\
\hline Ernest & Male & Catholic & Catholic & $\mathrm{PhD}$ & 15 & High & No God involvement & R1 \\
\hline Greg & Male & Catholic & Catholic & $\mathrm{PhD}$ & 20 & High & $\begin{array}{l}\text { Unsure of God } \\
\text { involvement }\end{array}$ & R1 \\
\hline David & Male & $\begin{array}{c}\text { Catholic/Jewish/ } \\
\text { Agnostic }\end{array}$ & Catholic & $\mathrm{PhD}$ & 11 & Moderate & No God involvement & R1 \\
\hline Samuel & Male & Jewish & Jewish & $\mathrm{PhD}$ & 40 & High & Refused to answer & $\mathrm{R} 1$ \\
\hline Ronald & Male & Jewish & $\begin{array}{r}\text { Protestant/ } \\
\text { agnostic }\end{array}$ & $\mathrm{PhD}$ & 17 & High & $\begin{array}{l}\text { Unsure of God } \\
\text { involvement }\end{array}$ & R1 \\
\hline Richard & Male & Jewish & Jewish & $\mathrm{PhD}$ & 20 & High & No God involvement & $\mathrm{CC}$ \\
\hline Thomas & Male & No answer & No answer & $\mathrm{PhD}$ & 17 & High & Refused to answer & R1 \\
\hline Brittany & Female & Other & Agnostic & $\mathrm{PhD}$ & 10 & High & $\begin{array}{l}\text { Unsure of God } \\
\text { involvement }\end{array}$ & $\mathrm{CC}$ \\
\hline George & Male & Protestant & Protestant & $\mathrm{PhD}$ & 41 & Moderate & No God involvement & R1 \\
\hline Jonathan & Male & Protestant & $\begin{array}{r}\text { Protestant/ } \\
\text { Catholic }\end{array}$ & $\mathrm{PhD}$ & 35 & High & $\begin{array}{l}\text { Unsure of God } \\
\text { involvement }\end{array}$ & $\mathrm{CC}$ \\
\hline Faye & Female & Protestant & Protestant & Master's & 18 & Low & God guided & $\mathrm{CC}$ \\
\hline Anne & Female & Questioning & Protestant & $\mathrm{PhD}$ & 12 & Moderate & $\begin{array}{l}\text { Unsure of God } \\
\text { involvement }\end{array}$ & $\mathrm{CC}$ \\
\hline
\end{tabular}

aFor personal belief in God's role in evolution: No God = human beings have evolved over billions of years from older life-forms and God was not involved in this process; Unsure of God = human beings have evolved over billions of years from older life-forms and I do not know whether or not God had anything to do with this process; God guided = human beings have evolved over billions of years from older lifeforms and God guided this process.

${ }^{\mathrm{b}} \mathrm{CC}=$ community college.

Twenty of $32(63 \%)$ participants identified as "atheist" or "agnostic," 6/32 (19\%) identified as a member of a denomination of Christianity, 5/32 (16\%) identified as Jewish, 1 participant identified as "questioning," 1 participant identified as "other," while another participant did not answer the question pertaining to religion on the survey. Participants were given pseudonyms to protect their identities. All other demographic information is reported in Table 2.

\section{Research Findings}

We report our findings by discussing instructor responses from the interviews and reporting the relative abundance 
Table 3. Selected results of qualitative analyses for each instructor

\begin{tabular}{|c|c|c|c|c|c|c|c|c|c|c|c|c|}
\hline Pseudonym & CA & NS & NG & $\mathrm{AFCT}$ & SP & LCT & $\begin{array}{c}\text { Is it their goal } \\
\text { to help students } \\
\text { accept evolution? }\end{array}$ & In-depth & Brief & Does not & $\begin{array}{l}\text { Evolution is } \\
\text { incompatible } \\
\text { with religion }\end{array}$ & $\begin{array}{c}\text { Number of } \\
\text { instructional } \\
\text { approaches cited } \\
\text { by literature }^{\mathrm{b}}\end{array}$ \\
\hline Neil & $x$ & $x$ & & & & & Yes & & $x$ & & & 0 \\
\hline Albert & $x$ & $X$ & & & $X$ & & Yes & & & $x$ & & 0 \\
\hline Martin & $x$ & $x$ & & & $X$ & & No & $x$ & & & $x$ & 3 \\
\hline Janet & & $x$ & $x$ & & & & No & & $x$ & & & 2 \\
\hline Chester & $x$ & $x$ & $x$ & & & & Yes & & $x$ & & $x$ & 3 \\
\hline Frank & $x$ & & $x$ & & & & No & & & $x$ & & 0 \\
\hline Edward & $x$ & $x$ & & $x$ & & & No & & $x$ & & & 0 \\
\hline Marie & & $x$ & $x$ & & & & Yes & & & $x$ & & 0 \\
\hline John & & & & & & & Yes & & & $x$ & & 0 \\
\hline Anthony & $x$ & $x$ & $x$ & & & & Yes & & & $x$ & & 0 \\
\hline Rose & & & & $x$ & & & No & & $x$ & & & 0 \\
\hline Rachel & & $x$ & & & $x$ & $x$ & Yes & & $x$ & & & 2 \\
\hline Lynn & & $x$ & $x$ & & & $x$ & No & & & $x$ & & 0 \\
\hline Victoria & & $x$ & $x$ & & & & No & & & $x$ & & 0 \\
\hline Craig & & $x$ & & $x$ & & & No & & $x$ & & $x$ & 2 \\
\hline Irene & $x$ & $x$ & & & & & Yes & & $x$ & & & 1 \\
\hline Emma & $x$ & $x$ & $x$ & $x$ & & & No & & $x$ & & $x$ & 0 \\
\hline Danny & $x$ & $x$ & $x$ & & & & Yes & & $x$ & & & 1 \\
\hline Theodore & $x$ & & & & & & No & & $x$ & & $x$ & 0 \\
\hline Charles & $x$ & & $x$ & & & & No & & & $x$ & & 1 \\
\hline Ernest & $x$ & $x$ & & & $x$ & $x$ & Yes & & $x$ & & & 1 \\
\hline Greg & $x$ & & & & & $x$ & No & $x$ & & & & 3 \\
\hline David & $x$ & & $x$ & $x$ & & & No & & $x$ & & & 1 \\
\hline Samuel & & $X$ & & $x$ & & & No & & $x$ & & $x$ & 0 \\
\hline Ronald & & $x$ & & & & & No & $x$ & & & & 3 \\
\hline Richard & & & & & & & No & & $x$ & & & 2 \\
\hline Thomas & $x$ & $x$ & & & & & No & & & $x$ & & 0 \\
\hline Brittany & $x$ & $x$ & & & & & Yes & & & $x$ & & 0 \\
\hline George & $x$ & $x$ & $x$ & & & & No & & $x$ & & $x$ & 1 \\
\hline Jonathan & $x$ & $x$ & $x$ & & & & Yes & & $x$ & & & 0 \\
\hline Faye & $x$ & $X$ & & & & & No & & & $x$ & & 0 \\
\hline Anne & $x$ & $x$ & & & & & No & & & $x$ & & 0 \\
\hline
\end{tabular}

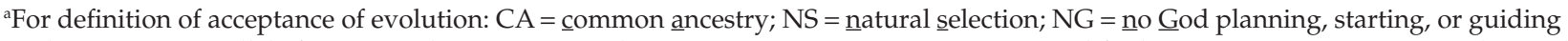

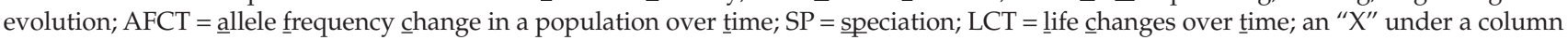
indicates that an instructor believed acceptance of that concept was required for student acceptance of evolution.

${ }^{b}$ Number of positive strategies refers to whether they used 1, 2, or 3 of the specific positive strategies that may help student accept evolution: discussing religious scientist role models who accept evolution, discussing the spectrum of viewpoints about religion and evolution, and telling students that religion and evolution can be compatible with one another.

of instructor-participant responses. Quotes are provided for instructor responses that are particularly illustrative for the reader to gain a deeper understanding of an instructor's perspective. In addition to our explanation of the results, we also provide tables that summarize individual instructor responses (Tables 3 and 4 ). 
Table 4. Selected results of qualitative analyses for each instructor

\begin{tabular}{|c|c|c|c|c|c|c|c|c|}
\hline \multirow[b]{2}{*}{ Pseudonym } & \multicolumn{4}{|c|}{ Barriers to discussing religion } & \multirow[b]{2}{*}{$\begin{array}{l}\text { Did they experience } \\
\text { a worldview conflict } \\
\text { with evolution? }\end{array}$} & \multirow[b]{2}{*}{$\begin{array}{l}\text { Have they been } \\
\text { challenged in class } \\
\text { about evolution? }\end{array}$} & \multirow{2}{*}{$\begin{array}{c}\text { Have they polled } \\
\text { their students } \\
\text { on acceptance of } \\
\text { evolution? }\end{array}$} & \multirow{2}{*}{$\begin{array}{l}\text { How many } \\
\text { students do they } \\
\text { guess reject evolu- } \\
\text { tion in their } \\
\text { classes? }\end{array}$} \\
\hline & $\begin{array}{l}\text { Classroom } \\
\text { constraints }\end{array}$ & $\begin{array}{l}\text { Inappro- } \\
\text { priate } \\
\text { class }\end{array}$ & $\begin{array}{l}\text { Lack of } \\
\text { training }\end{array}$ & $\begin{array}{c}\text { Personal } \\
\text { beliefs }\end{array}$ & & & & \\
\hline Neil & & & & $X$ & No & No & No & $<10 \%$ \\
\hline Albert & & $X$ & & $X$ & Yes & No & No & No perception \\
\hline Martin & & & & & Yes & Yes & No & $<10 \%$ \\
\hline Janet & & & & & No & Yes & No & $5-15 \%$ \\
\hline Chester & & & & & No & No & No & A "fair number" \\
\hline Frank & & & & & No & No & No & No perception \\
\hline Edward & & $x$ & & & No & No & No & Vague \\
\hline Marie & $x$ & & & & No & No & No & No perception \\
\hline John & & & $x$ & $x$ & No & No & No & $5 \%$ \\
\hline Anthony & & $x$ & & & No & No & No & $10 \%$ \\
\hline Rose & & $x$ & $x$ & & No & Yes & No & No perception \\
\hline Rachel & & & & & No & Yes & No & No perception \\
\hline Lynn & & & & & Yes & Yes & No & $40 \%$ \\
\hline Victoria & & & $X$ & $X$ & No & No & No & $25 \%$ \\
\hline Craig & $x$ & & & & No & No & No & $5 \%$ \\
\hline Irene & & & & $X$ & No & No & No & Very few \\
\hline Emma & & & & $X$ & No & No & No & $20 \%$ \\
\hline Danny & & & & & Yes & Yes & Yes & $20 \%$ \\
\hline Theodore & $X$ & & & $X$ & No & No & No & No perception \\
\hline Charles & $X$ & & & & No & No & No & Vague \\
\hline Ernest & & & & & No & No & Yes & No memory \\
\hline Greg & & & & & No & Yes & Yes & $34 \%$ \\
\hline David & $x$ & & & & No & No & No & No perception \\
\hline Samuel & & & & $X$ & No & No & Vague & Vague \\
\hline Ronald & & & & & No & Yes & No & $\begin{array}{r}\text { One to two } \\
\text { students }\end{array}$ \\
\hline Richard & & & & & No & No & No & No perception \\
\hline Thomas & & & & & No & No & Vague & Vague \\
\hline Brittany & & $X$ & $X$ & & No & No & No & No perception \\
\hline George & & $X$ & & $X$ & No & No & No & No perception \\
\hline Jonathan & $X$ & $X$ & & & Yes & No & No & No perception \\
\hline Faye & & & $X$ & & No & No & No & No perception \\
\hline Anne & & & & & Yes & No & No & No perception \\
\hline
\end{tabular}

\section{Do Instructor Participants Have a Goal to Help Students Accept Evolution?}

Instructor Participants Have Different Definitions of "Acceptance of Evolution." When asked to provide a definition of what it means to "accept evolution," instructors gave a wide variety of responses. The majority of instructors said acceptance of evolution had to include acceptance that either natural selection is the main mechanism by which life has diversified and/or acceptance that all of life on Earth shares a common ancestor. A minority of instructors said that acceptance of evolution includes acceptance that speciation occurs, acceptance that allele frequencies in populations of organisms change over time, and acceptance that life changes over time. See Table 3 for each individual instructor's definition of student acceptance of evolution.

Instructors were divided on whether a student had to accept that evolution occurred without God/god(s) starting, 
planning, or guiding evolution in order for that student to be considered an "accepter." Some instructors thought that students could intertwine a belief in an influence of God $/ \operatorname{god}(\mathrm{s})$ on evolution. These instructors explained that whether or not a student accepts evolution is not dependent on the student's views of supernatural influences, because the influence of God/god(s) is outside of the purview of science. For instance, Edward thought that what mattered for student acceptance of evolution was that students accept the natural phenomenon that biologists have studied and observed:

"I would say that if a person told me that they believe all life on earth shares a common ancestor and that natural selection has been a major mechanism for adaptation, then I would agree that they accept evolution. Questions of 'what started it all' or 'whether God has a hand' is [sic] out of the scope of science and biology, and that is partly why I think religion and science deal with different domains philosophically." (Edward)

In contrast, other instructors explained that acceptance of evolution is not compatible with the view that God/god(s) had anything to do with evolution. These instructors, including Marie, felt that, in order to accept evolution, you have to accept that it could happen by only natural processes:

"I would be concerned that the student feels the need to impose a higher, directed order on natural forces. It implies that the student doesn't think that evolution could occur on its own, by purely natural forces." (Marie)

A third category of instructors emerged who said that a student being an accepter depended on what role the students thought God/god(s) played in evolution. These instructors thought a student would be considered an accepter of evolution if the student believed God/god(s) started evolution. However, if a student thought God/god(s) planned or guided evolution, then that would be inconsistent with the idea that evolution progresses in a nondetermined direction, which is an important part of evolutionary theory:

"God starting things out is probably consistent with believing in evolution. But since a key aspect of evolution is natural selection based on random mutation any guiding to me seems inconsistent with this key aspect of evolution." (Neil)

A fourth category of instructors felt as though we should not have a dichotomy of "accept" or "reject" and that a student who believes God/god(s) had a role in evolution is somewhere in between a "rejecter" and "accepter" of evolution:

"I think for most purposes 'reject' is too hard a judg-
ment on that person. She accepts a hybrid interpreta-
tion under which both evolutionary and divine design
processes act." (Frank)

Most Instructor Participants Do Not Know Whether Their Students Accept Evolution and Have Not Been Challenged about Evolution in Class. Very few instructors reported that they had asked their students whether they accepted evolution, and these instructors reported that $\sim 20-34 \%$ of their students rejected evolution (Table 4). Some instructors polled their students with multiple-choice questions either through anonymous clicker questions or surveys, and others had students write essays about their views on evolution. The instructors who had students write essays did not do so with the intention of polling their students but to give them the chance to explore their conceptions and beliefs about evolution. Many of the instructors who had not polled their students said they thought it would alienate students if they were probed about their beliefs.

Although the vast majority of instructors had not polled their students, many of these instructors were willing to guess what percent of their students reject evolution. Those instructors who were willing to guess generally thought that very few (often $<10 \%$ ) of their students rejected evolution (Table 4). Further, only a minority of instructors had ever been challenged by students about evolution, which may have led many instructors to perceive that most students did not have a problem with learning about evolution.

The Majority of Instructor Participants State That Helping Students Accept Evolution Is Not an Instructional Goal. We let instructors use their own definitions of acceptance of evolution to answer the question of whether it was their goal to help students accept evolution. While relying on instructor definitions adds noise to our data, we felt what was most important was instructors' own perception of what they think their role as an instructor is, and this is dependent on their own definitions of student acceptance of evolution.

When asked whether they considered helping students to accept evolution as part of their goal when teaching evolution, the majority of instructor participants said that it is only their goal to help students understand evolution and not to help students accept evolution. According to these instructors, changing a student's mind about whether evolution is true is not a focus of their instruction. They indicated that they were teaching students to be critical thinkers rather than persuading them to accept evolution. Interestingly, these instructors perceived that trying to change student beliefs would make them feel manipulative and authoritarian and even that it may be an inappropriate motive for instruction:

"I give them the information and I'm pretty straightforward. This is it, evolution is a fact, deal with it. But I'm not out to twist their views." (Anthony)

"I'm there to teach them and so as long as you can ma-
triculate through my class and understand concepts
and how natural selection operates and how genetic
change in population occurs etc., you're fine. If you
don't believe that that occurs then that's your own
personal choice. But you just have to know the stuff
and if you're a [biology] major, I hope you're not my
doctor." (Craig)
"My goal is for them to understand it and then it's
their job to decide whether to accept or reject it. I don't
have an agenda." (Rose)

However, a minority of instructors said they did think it was part of their goal to help students accept evolution. Some considered acceptance of evolution essential for learning: 
"I think you can't separate one from the other [acceptance from understanding]. Really, I think if students are not open and they're not accepting the material then they can't learn." (Ernest)

Other instructors who said acceptance was their goal questioned whether a student could practice biology if he or she did not accept evolution. Because evolution is the foundation of biology, these instructors thought acceptance is necessary in order to practice biology:

"I don't understand how a student who wants to be a biologist, and I'm teaching mostly biology students, I don't understand how a biology student, somebody who wants to do that, can do anything in science and biology without believing that. That's the guiding principle, is nothing makes sense [in biology without evolution]." (Marie)

Finally, some of the instructors who said acceptance was their goal did not distinguish between acceptance of evolution and understanding of evolution. According to them, if a student understands evolution, that means he or she accepts evolution:

\begin{abstract}
"I don't see a difference between understand and accept. If you understand, you accept. The same way if I explain how the water moves from the soils to leaves, or I explain how species evolve. They need to understand water doesn't move from the soil to the leaves because the leaves need water, it moves because there is a gradient water potential. And species composition doesn't change [because it needs to], it changes because one species has characteristics that increases [sic] their fitness. That's what I explain and if they understand that, they accept it." (John)
\end{abstract}

\section{Do Instructor Participants Address the Potential Conflict between Religion and Evolution in Their Classes?}

Very Few Instructor Participants Have In-Depth Discussion of Religion in the Context of Evolution. In addition to asking instructors about their goals when teaching, we also asked them to self-report on the extent to which they discuss religion when teaching about evolution and why they choose to discuss or not discuss religion. Notably, very few instructors said that they addressed religion and evolution in depth ("in depth" is defined as using a whole class period to discuss religion and evolution or mentioning it several times throughout the semester). The vast majority of the instructors never discussed it or discussed it briefly. Some instructors addressed religion in a way that made it seem incompatible with evolution. In this section, we present the quotes that illustrate the extent to which religion is discussed in our participants' classrooms. For instructors who do not talk about religion, elaboration of their reasons for not discussing religion will be discussed later in the section on barriers to discussing religion.

The following quote is one example from those instructors who do not discuss religion at all in relation to evolution in their courses. Many of them said they never bring up religion in their courses because it did not seem relevant to the scientific content of the course:

"You might talk about it [religion] in a different class that has to do about contrasting evolution with creationism, or something like that, but this is not what I'm doing here. I'm not doing that here." (Anthony)

The following quotes are illustrative of about half of the instructors, who said they mention religion only briefly when they teach evolution. When they do mention religion in their classes, they generally contrast religion with science, often explaining how religious ideas are untestable or outside the realm of science. However, this was usually presented as a quick disclaimer and was not emphasized to students:
"I have occasionally compared religion to science, but not routinely or ever in depth." (Edward)
"I don't think I really directly talk about religion but I'll say that other ideas about the origins of life and species and so on that aren't based on natural expla- nation or natural phenomenon aren't testable and so they don't fall within the realm of science and so you don't see them presented in this textbook in that way. So that's usually how I'll sort of touch on it." (Chester)

Very few instructor participants said they either talked about religion several times while teaching evolution or spent at least one class period seriously discussing religion in relation to evolution. All of these instructors reported that their goal in discussing religion was to show students that religion and evolution do not have to be in conflict. For instance, this instructor explained how he tells students that religion is one way of viewing the world and intentionally does not discount the importance of religion to certain students' lives. The instructor believes that being accepting of religion in class helps students to be more open to evolution:

\begin{abstract}
"Very early on the first day of the class-the first discussion of the class-sometimes very often my classes start off with discussions about the nature of science and about how science is the way of explaining and understanding the universe and in that it is one of many ways of explaining and understanding the universe. That it is probably the narrow-minded person who uses any single particular way of knowing to understand and perceive and enjoy life experiences. And it's probably a more mature thinker who draws on several different ways of knowing to enjoy that experience. I don't discount religion as a valid way of experiencing life. It is one set of paradigms that people use, sometimes they work sometimes they don't. Sometimes they bring great comfort, sometimes they don't-whatever, they have their role for some people. In that first discussion I think I neutralize a lot of feelings that could later turn into aggression towards some of the more controversial scientific theories such as evolution." (Ronald)
\end{abstract}

One instructor noted how some scientists think that instructors should avoid talking about religion, but he disagreed with those other scientists. According to him, ignoring religion when teaching evolution becomes awkward, because it is such a notable point of contention: 


\begin{abstract}
"Some scientists think you should just avoid the whole creationism thing itself and not even mention it. I don't agree with that approach. I think that if you do that then creationism is this 800-pound gorilla that's sitting in the corner of your classroom that you seem to be carefully ignoring. I mean, I prefer to bring the gorilla out and sit the gorilla down center stage and start talking about the gorilla." (Greg)
\end{abstract}

Instructors also discuss in their classes how some religious views can be more compatible with evolution than others. The intent of this discussion was to show that, contrary to some assumptions, many religions are compatible with evolution. For instance, Martin highlighted in his course how evolution is not in conflict with religion as a whole, although it is in conflict with some fundamentalist religious views:

\begin{abstract}
"In terms of strategies it's a pretty straightforward one hour lecture with PowerPoints and I talked a little bit about the history and objections to evolution dating from Darwin's time and I note that the one that is still with us is that it runs counter to a literal interpretation of the Bible. I note that the conflict-that there is no conflict between religion and evolution. There is a conflict between evolution and certain sects of Christianity and many denominations of Christianity have no trouble whatsoever with evolution. Most practitioners of Islam have no trouble with evolution. The fundamentalist Muslims do. Other religions have no problem with evolution. So I make the point that it is not a matter of evolution vs religion-it is a matter of certain denominations of religion being opposed to the idea of evolution, of an old Earth, a distinct ancestry of humans and other forms of life and of evolution in general." (Martin)
\end{abstract}

Notably, all three instructor participants who had in-depth discussions about religion and evolution in their classes said they did not consider helping students to accept evolution as part of their goal when teaching (Table 3). Further, all three of these instructors reported growing up in a household with a religious affiliation (Table 2). Two of the three instructors identified with a religious group and reported that they were unsure of what role God played in evolution (Table 2). From the data we collected, there was nothing else that distinguished these instructors from other instructors in our subject pool.

Among instructors who do discuss religion, some of them reported discussing religion in a way that seemed incompatible with religion. Oftentimes, this seemed unintentional, but instructors would imply that knowledge from religion is inferior to knowledge from science, because it is not based on testable, observable phenomena. Other instructors, such as Samuel, were more explicit in making religion seem incompatible with evolution:

"(I would say), 'there's a terrible wind blowing through America ... that is trying to impose religion as science. It is out to destroy America, because it is not simply evolution. Evolution is built on genetics. It's built on chemistry. It's built on physics. It's built on astronomy, all of the sciences. If you believe in creationism, you can't believe in any of the foundations of science and that will destroy America. You will destroy America.' Pretty harsh. There is a deathly silence over the classroom." (Samuel)

\section{Do Instructor Participants Use Instructional Practices That Align with Suggestions in the Literature for Increasing Student Acceptance of Evolution?}

Many instructor participants do not report using instructional practices that align with suggestions in the literature for increasing student acceptance of evolution.

Although most instructor participants did not report spending significant time discussing religion in the context of evolution, they may still be utilizing instructional practices that have been recommended to help mitigate conflict between religion and science (Smith, 1994; NAS, 1998, 2008; Southerland and Scharmann, 2013). In our interviews, we asked instructors whether they had provided students with examples of religious scientist role models who accept evolution (Winslow et al., 2011), whether they had discussed the spectrum of viewpoints about religion and evolution (NAS, 1998), and whether they had told students that religion and evolution could be compatible (Smith, 1994; NAS, 2008; Southerland and Scharmann, 2013; Barnes et al., in press, 2017). Further, we asked the instructors how and why they choose, or do not choose, to implement these practices. Based on a small but growing research literature (Roth, 1997; Wiles and Alters, 2011; Winslow et al., 2011; Manwaring et al., 2015; Barnes et al., in press, 2017), these strategies have the potential to increase student acceptance of evolution and make religious students feel more comfortable in class.

Although most instructor participants had said it was not their goal to help students accept evolution, almost half of those instructors who said acceptance was not their goal said they had used at least one instructional strategy that has the potential to increase student acceptance of evolution. Thus, we looked at all instructor responses, regardless of whether they said that it was their goal to help students accept evolution. About half of all the instructor participants said they were using at least one of the three strategies at some point when they teach about evolution.

Instructor participants who provided students with religious scientist role models said they did so with the intent to show religious students that there are people who have religious beliefs and also accept evolution. The instructor participants wanted students to know they do not have to choose between their religious beliefs and evolution. A few instructors used themselves as religious scientist role models for their students:

\footnotetext{
"I point out that I'm a Catholic, and I'm an evolutionary biologist, and you go to [a Catholic university], where I went, and they have a whole evolutionary biology curriculum, there are evolutionary biologists on the faculty." (Greg)

"I don't discuss other people's belief systems at length because I don't feel I have the capacity or perhaps even the right to but I never hesitate in class to talk about my own perspective towards religion and God and morality and things like that and so because I'm open about those things with my students, I think students appreciate that. They see at least one role model, me perhaps, in that I am an evolutionary biologist and I have found a way very easily to also have religious beliefs and live a moral life and all of those things. I'm not an atheist and yeah we talked about that in class.
} 
And I think students see that you don't have to have that forced dichotomy." (Ronald)

However, most instructors who provided students with religious scientist role models who accept evolution did so using examples of other scientists:

\begin{abstract}
"I have in the past shown a film about the human genome project. And the guy who runs the human genome project is Francis Collins and he's a deeply religious man and so yeah, I think it's worthwhile to say there's nothing incompatible with religion and science." (Richard)
\end{abstract}

The instructor participants who said that they talk about various viewpoints on the relationship between religion and evolution said they did it to show students that several religious groups do accept evolution. These instructors wanted students to know that evolution and religion can be compatible. Some instructors, such as Craig, use national polling results that disaggregate acceptance of evolution by religious groups as a way to show students different religious viewpoints:

\begin{abstract}
"The one thing I do is I show a Pew survey that was done, it was pretty dated now I think, in the early 2000 's that showed the different religious faiths and their percentage of acceptance of a statement like "the best explanation for the origins of human beings is through evolution.'" (Craig)
\end{abstract}

Other instructors describe ways in which religious individuals have reconciled their religion with evolution:

\begin{abstract}
"I treat the notion superficially, but I do treat it. In fact, one of the additional handouts I use in at least that introductory class where we spend a significant amount of time on evolution is an article that describes Pope John Paul's acceptance of evolutionary theory and I use that as a platform to have that discussion." (Ronald)
\end{abstract}

Many instructor participants explicitly told students that evolution and religion can be compatible. These instructors would incorporate the philosophy of science and describe to students that methods of science are neutral to the existence and influence of a God/god(s). They stress to their students that science does not rule out the existence of a higher power:

\footnotetext{
"And I say, oh if you accept evolution, because I think that's where they get into trouble, they think that, okay if I accept evolution then I can't be a good Mormon or a good Christian or a good whatever, and so my idea is you know that you can go to church and still believe in evolution, it's not incompatible." (Richard)

"In my introductory biology class it comes up very explicitly when I talk about the philosophy of science. So we have a unit on evolution and now we're talking about what science is. I contrast science and religion and I talked about how they ask different questions. Just because science has nothing to say about the deeper truth that doesn't mean that it's saying that there is nothing." (Rachel)
}

A minority of instructor participants used more than one of the strategies outlined above. Notably, most instructors who used more than one of these practices did not think it was their goal to help students accept evolution. Only a few instructor participants used all three strategies, and all of those instructors were the instructors who also discussed religion and evolution in depth in their course.

\section{What Kinds of Barriers Do Instructor Participants Perceive in Addressing Conflicts between Religion and Evolution in Their Classes?}

Instructor Participants Perceive Multiple Barriers to Discussing Religion while Teaching Evolution. Because a significant number of instructor participants were not discussing religion, we explored what barriers might exist for them doing so. The majority of instructor participants said that they perceived barriers to discussing religion in class, which made them hesitant about incorporating religion into classroom discussions. Of the instructors who perceived barriers to discussing religion in relation to evolution in their class, half of them reported that they still discussed religion in the context of teaching evolution. This indicates that for some instructors, these perceived barriers are not sufficient to stop them from incorporating discussions about religion into their evolution instruction.

Many instructor participants believed there were barriers to discussing religion when teaching evolution. Instructors cited classroom constraints, the appropriate domain of discussion in a science class, lack of training in issues involving religion and evolution, and personal beliefs about religion and evolution. These are discussed in more detail below.

Classroom Constraints. Some instructor participants felt that the logistics of their classroom were a barrier to discussing religion. The instructors usually referenced large class sizes and limited time as barriers. The instructors thought that large classrooms were not amenable to such personal discussions and that time constrained them because they had too much content to present:

\begin{abstract}
"And the other thing is, we're teaching a class of over 300 students. It's very different if I'm in a classroom of 30 students to have a discussion about this ... there's only so many things that we can go into and if we spent you know three or four weeks discussing all these different aspects, we would really lose out and I think we would do a disservice to the students to do that." (Charles)
\end{abstract}

"They've got about just enough time to handle what I give them and not anything else." (Jonathan)

Appropriateness of the Biology Class. Also, some instructor participants said that their science class was not an appropriate forum for discussions of religion and evolution. These instructors often said that discussions about religion in the context of evolution are only appropriate for a philosophy class, not a science class:

"Probably one of the reasons [this would be challenging] is that what we are really talking about is 
the difference between science and philosophy, and because we're really talking about philosophy and this is a science class ... it's not really on the table." (Anthony)

"That gets into an area where you're starting to bring religion into the science curriculum and so that would be the reason for not doing that." (Jonathan)

"I guess what I would find challenging about that is that it just seems to me that implementing a strategy like that would be more consistent with offering a class on religion and evolution. And less consistent with a class that is specifically designed to discuss evolution. I don't think it's the right venue." (Albert)

Lack of Training. The lack of training in discussing religion related to evolution was another barrier that emerged. Some instructor participants said they did not feel they were knowledgeable enough about the topic of religion and evolution to talk about religion to their students. Because it is such a sensitive topic for many students, instructors indicated that they wanted to be sure they have the knowledge to properly handle potential challenges from students:

"I am very uncomfortable with that because I am not a religious expert and that is really outside my realm." (Victoria)

Personal Beliefs about Religion. Of all the barriers cited, personal beliefs about religion and evolution was mentioned most frequently. Many instructor participants said that their own beliefs about religion would be a barrier to productive discussions in class. Much of the time this was due to the instructor's belief that aspects of religion are incompatible with evolution:

"I'm not going to get into a major debate over science
versus religion. Somebody's religion-my religion is
very personal to me. I don't believe everything that
my religion says I should believe. I don't want to bring
God into the equation. I really do not want to do that
because I don't know what kind of God I believe in.
I do not believe in the God of my Bible or the less
threatening God of your Bible. I have my own fuzzy
... [belief in what God is]." (Samuel)

"There is a real fundamental problem with being an evangelical Christian if you believe that you are saved by grace. The problem with that is that if we evolved then there was no Fall, and if there was no Fall, then there is no need for atonement of Jesus dying on the cross. So there's a real fundamental conflict there if you say you are a Christian and you believe in Jesus and you believe in the notion of needing to be saved with the basic tenets of evolution that say we evolved. So even though these folks say they are evangelical Christians I mean that's fine and I am not someone who disregards the value of having a spiritual life. I think that that part is actually quite important but the notion that you need to be saved and that the way to be saved is to believe in Jesus Christ is really at odds with the idea of an evolved species." (Albert)

These personal beliefs as a barrier to incorporating discussions about religion are particularly interesting, because they relate to other findings about instructor personal beliefs from the interviews. Most instructors do not personally think that a God/god(s) had anything to do with evolution. In our survey, $69 \%$ of instructors reported that they believed God/god(s) had nothing to do with evolution, $22 \%$ of instructors reported they did not know whether God/god(s) had anything to do with evolution, and only 3\% reported that they thought evolution was guided by God/god(s). No instructor thought that God/god(s) started evolution or that God/god(s) made humans in their present form. Six percent of instructors declined to answer the question.

Further, the overwhelming majority of instructors said they had never experienced a conflict with evolution and their personal religious beliefs. These instructors fell into two categories: 1) those who did not have religious beliefs and did not grow up in a household that was religious, so there was never an opportunity for a conflict; and 2) those who grew up in a religious household but were taught that religion and evolution were not in conflict.

The following are quotes from instructors who did not experience a worldview conflict with evolution:

"I was brought up Jewish, and there's some way, that even though Judaism has basically the same story of 6 days and the 7th day, God rested and all that, that there's some way that Judaism says that that all has to fit in with what we know about how life works. If we know that life works through evolution, we have to figure out how this fits into that, rather than the other way around. I don't remember having any sort of tribulations to my worldview when I thought about evolution, or any of the hard sciences, any of the sciences. To me, evolution comes down to a belief in science [...]. For me, I don't see any evidence for a supreme being in science, and somehow that's always seemed natural to me. I don't remember any sort of crisis growing up about that." (Neil)

"I'd say no [I didn't experience a conflict]. I crave empirical understanding and always have and so it was easy. I wasn't raised religious so I didn't have any sorts of understandings prior to this point that I had to reconsider really. I was a blank slate and so as I began to understand this, I was like "This is incredibly cool.' You can understand how this stuff works now." (Craig)

The minority of instructors who did experience a conflict were either religious at one point but "chose science over religion" or remain religious to this day but had to find a way to reconcile religion and evolution:

\begin{abstract}
"It's certainly a struggle in the sense of not knowing where God took over evolution and initiated evolution. There's no way of knowing that sort of thing and of course you struggle with it." (Jonathan)
\end{abstract}

"I went to a very conservative college and I remember I took a couple of religion classes where they just said what I thought were just completely ridiculous statements. So I guess at that point I was 18 or 19 I was kind of trying to, you know, my parents weren't overly religious but some of my other family was and I was kind of trying to piece it together and put it into perspective of being a biology major and what everybody believed and I had a couple these classes ... 
I had one teacher I remember that was lecturing us on the book of Genesis and he told us that God put dinosaur bones into the earth to test our faith [laughs] and I was just like, 'I know I'm only 18 but that's the most ridiculous sounding thing I've ever heard.' So actually I was kind of being exposed to a couple of ... it's just so ridiculous, there's no way I can believe this. Things that really force me to, I have to go with what seems like logical and reasonable to me and I just can't accept that." (Anne)

\section{DISCUSSION}

In this study, we explored the perspectives of instructors who have taught about evolution to undergraduates. Given the flexibility in what college biology instructors can choose to teach, the instructional decisions of college instructors are important for understanding the landscape of evolution education. While there is a rich literature on college student understanding of evolution (Bishop and Anderson, 1990; Lawson and Worsnop, 1992; Nehm and Reilly, 2007; Hermann, 2012) and college student acceptance of evolution (Rice et al., 2010; Wiles and Alters, 2011; Winslow et al., 2011; Abraham et al., 2012), we know of only two other studies that have looked into the perspectives of college biology instructors regarding student acceptance of evolution (Rice et al., 2015; Wilbur and Withers, 2015). However, these studies did not explore the perceived goals of college instructors when teaching about evolution, whether and how they discuss religion when teaching about evolution, and what perceived barriers exist to discussing religion when teaching about evolution. Thus, the current literature in evolution education seems to be devoid of the perceptions of the people actually teaching evolution at the college level. This interview study of instructors teaching in public institutions of higher education in Arizona represents the first step in exploring these questions, which could be followed up with observational studies of instructor practices in the classroom and the impact of these practices on students.

\section{Many Instructors Do Not See Student Acceptance of Evolution as Part of Their Instructional Goals}

Despite the extensive literature on student acceptance of evolution (Sinatra et al., 2003; Ingram and Nelson, 2006; Miller et al., 2006; Espinosa and Guillermo, 2009; Nehm et al., 2009; Nadelson and Sinatra, 2010; Nadelson and Southerland, 2010; Rutledge and Sadler, 2011; Wiles and Alters, 2011; Abraham et al., 2012; Heddy and Nadelson, 2012; Rissler et al., 2014), we found that the majority of instructor participants did not think increasing student acceptance of evolution was their instructional goal. This debate on whether student acceptance of evolution is important has been extensively discussed in evolution education literature and, in line with our findings, a consensus about whether it should be the goal of evolution education to increase student acceptance has yet to emerge (Cobern, 1994, 2004; Smith, 1994; Alters, 1997; Sinatra et al., 2003). Notably, this distinction between understanding and acceptance seems to be a unique characteristic of the topic of evolution and is not an area of contention for other core concepts of biology (AAAS, 2011, Brownell et al., 2014). If instructors do not debate whether it is their goal for students to understand or accept structure function, pathways and transformations of energy and matter, information flow, or systems should the core concept of evolution be any different and, if so, why?

In our study, we did not ask instructors what might change their minds to include acceptance as an instructional goal. However, if college student acceptance of evolution is to improve, then determining how to effectively communicate with college biology instructors on the importance of acceptance in evolution education could be key. Future studies could explore what types of evidence would be effective in convincing instructors that acceptance is a worthy goal of evolution education.

\section{A Definitional Problem of Acceptance of Evolution}

One possible reason that instructors may not think it is their goal to help students accept evolution is how they personally define acceptance of evolution. As we found in this study, some instructors define acceptance of evolution as necessarily excluding the potential role of a God $/ \operatorname{god}(\mathrm{s})$ in creating evolution. If instructors think that students cannot believe a God/god(s) created evolution in order to accept evolution, then instructors may not think acceptance is their goal, because to get students to accept evolution, they would be asking some students to give up a belief in God/god(s). However, if instructors allow for the possibility of a God/god(s) in their definition of acceptance of evolution, then it may seem less of an ethical dilemma. With a looser definition of acceptance of evolution, which allows students to incorporate an optional role for a God/god(s), perhaps more instructors would indicate that it is part of their goals for students to accept evolution. Because religious beliefs tend to be salient to a student's identity and because the methods of science are limited to studying the natural world, we encourage instructors to allow for the possibility of a student maintaining a belief in a possible role of God/god(s). While our study offers an initial exploration into this topic, a thorough treatment of the definition of acceptance of evolution is beyond the scope of this paper. A future publication by the authors will treat this issue in more depth.

\section{Potential Barriers to Instructors Discussing Religion in the Context of Evolution}

Instructor participants perceive multiple barriers to discussing religion in the context of evolution in their class. Some instructor participants said they did not think a science class is the appropriate forum for discussing religion in relation to evolution. Many instructors thought that discussions about religion in relation to evolution should be reserved for a religion or philosophy class and not a science class. While studies have shown that discussing religion in the context of evolution can be a useful way to demonstrate the nature of science (Clough, 1994; Smith, 1994; Alters and Nelson, 2002), it may be that instructors are not aware of this or do not consider this to be a part of their evolution units. Using religion as an example, one can compare and contrast what is science (i.e., evolution) to what is not science (i.e., creationism). An instructor can demonstrate the types of knowledge that science accumulates (i.e., information about the natural world) in contrast to the type of knowledge that religion accumulates (i.e., existence of God/god(s), influence of 
God/god(s), prescriptions of how to live one's life morally). In this sense, an instructor can both teach about the nature of science and also potentially diminish students' perceived conflict between religion and evolution by explaining that they are different domains of knowledge.

Additionally, instructors indicated that they did not have the experience or training to discuss religion in the context of evolution in their classes. Indeed, research shows that when instructors feel they are not knowledgeable in a content area, they tend to spend less time presenting that content in class and experience anxiety when they do present the content (Griffith and Brem, 2004). Instructors may need to become more familiar with the evolution-religion realm to feel more comfortable implementing strategies that deal with this content. The NAS's handbook Science, Evolution, and Creationism (NAS, 2008) and the book Evolution vs. Creationism (Scott, 2005) are both potential resources for instructors thinking about conflicts students may face with evolution. Books such as Ken Miller's Finding Darwin's God (Miller, 1999) and Francis Collins' The Language of God (Collins, 2006) can help instructors become familiar with religious ideas about evolution, from a biologist's perspective. Further, the National Center for Science Education has a Web page on science and religion that offers a list of practical resources for those interested in learning more about the topic (http://ncse.com/religion).Venues where biologists can interact with philosophers of science or biology and society programs may give college-level biology instructors the opportunity to become more familiar with these ideas. Both of the authors are housed in a school of life sciences in which there is frequent interaction among evolutionary biologists and philosophers; institutional structures such as this could be a way to encourage these conversations and break down barriers.

The most cited barrier to discussion of religion in the context of evolution was an instructor's personal beliefs about the relationship between religion and evolution. The prevalence of personal beliefs as a barrier to discussing religion in the context of evolution prompted us to examine other aspects of participants' personal beliefs. These were not explicitly cited as barriers by the instructors but could contribute to instructors not discussing religion in the context of evolution in biology classes. Many instructor participants did not believe there were many students in their classes who rejected evolution. The average reported guess of rejection rates by an instructor about his or her class was $\sim 15 \%$, with some instructors believing the rejection rate was as low as $5 \%$ in their classrooms. However, only three instructors had polled their classes to determine the percentage of students who rejected evolution, and these instructors found that $20-34 \%$ of their students rejected evolution. In addition, the overwhelming majority of instructors reported they have never been challenged by a student about evolution in class, which could be why they believe that most of their students accept evolution. However, a student not explicitly challenging an instructor's instruction may be a poor indicator for student acceptance of evolution, given that studies indicate that some students find science, technology, engineering, and mathematics (STEM) instructors intimidating and unapproachable (Seymour, 2000). Further, religious students may be unlikely to raise concerns in a secular environment if they feel that environment is unsupportive of religion. Past research has shown that $30-50 \%$ of students in biology classes reject aspects of evolution (Moore and Kraemer, 2005; Verhey, 2005; Ingram and Nelson, 2006) and up to $26 \%$ of students are undecided about evolution (Espinosa and Guillermo, 2009), so it is likely that instructors are underestimating rejection rates and uncertainty about evolution in their classes.

Finally, instructors may struggle when trying to relate to their students' religious conflicts with evolution. Only a small fraction of instructors reported that they experienced their own worldview conflict with evolution at any time in their life, which may be due to the low levels of religious belief among this population. Further, the majority of instructor participants reported that they believed that God/god(s) had nothing to do with evolution, indicating that they take a primarily atheistic view of the diversification of life. While an atheistic view of evolution is sometimes seen as more compatible with a scientific view, there may be students who do accept evolution but also believe a God/god(s) planned, started, or guided the process. It might be difficult for a secular instructor to identify with the struggles and challenges that religious students may face when learning about evolution. However, if secular instructors want to help religious students become more comfortable with evolution, they likely will need to become more aware of student religiosity, rejection of evolution, and the challenges facing students who may be going through a worldview conflict with evolution. Although instructors who personally believe that there is an irreconcilable conflict between evolution and religion may feel it is dishonest to tell students that the two are reconcilable, they can still show students examples of other prominent scientists and religious leaders who have reconciled evolution and religion.

\section{Implications for Equity in Undergraduate Biology}

Although this was not the focus of our study, a possible extension of our findings is how instructional practices are impacting how religious students feel in the classroom. While discussions of diversity in STEM have traditionally focused on individuals from diverse races/ethnicities, gender identities, LGBTQIA (Lesbian, Gay, Bisexual, Transgendered, Queer, Intersex, Asexual) identities, and abilities/ disabilities, we envision a need to broaden our efforts to diversify STEM to include individuals from diverse religious backgrounds. A disconnect between instructor and student beliefs about religion could possibly filter out religious students from pursuing careers in biology, thereby contributing to a less religiously diverse scientific community. Instructors could be inadvertently selecting against students who are religious, and this could impact how religious undergraduates feel about how they belong in the biology community. If religious students feel their beliefs are not compatible with the dominant views of the biology community, this could lead to students choosing different career paths in fields in which they feel their personal beliefs are more compatible with the dominant views. If instructors insist that students have to choose between their religious identities and their biology identities, then students are likely to choose the identity that is most salient to them; for religious introductory biology students who have not had much experience with science, religious beliefs will likely be more important to them.

Religious student comfort when learning evolution could impact ethnic diversity in evolutionary biology as well as 
religious diversity. In recent years, the National Science Foundation (NSF) has released data that show doctoral degrees in evolutionary biology are rarely awarded to African Americans. Indeed, in 2011 no doctoral degrees in evolutionary biology were awarded to African Americans, while other areas of biology granted $\sim 5 \%$ of their doctoral degrees to African Americans (National Center for Science and Engineering Statistics, 2011). In a recent study, researchers linked this underrepresentation of African Americans in evolutionary biology at least partially to their high levels of religiosity (Mead et al., 2015). As we strive to diversify who gets to participate in science (Tanner, 2013; Bangera and Brownell, 2014; Eddy et al., 2014, 2015), it is important that instructors are conscious of the biases that may result in the exclusion of a cultural group from evolutionary biology.

\section{Limitations}

This study was conducted with instructors in public institutions of higher education in Arizona. Arizona is a relatively conservative state and, in 2009, Arizona was ranked as the eighth in the nation for percent registered Republicans (CNN, 2005; Gallup, 2009). Therefore, these results could be unique to the context of this geographic area and political climate. While we are not aware of any state mandates on what Arizona college instructors are not allowed to teach and interview participants did not mention any statewide policies, instructors may still be indirectly affected by their perceptions of state governance or even state politics. It will be important to replicate this study in other geographic areas to determine whether the findings are consistent or if there are unique geographical constraints that impact these instructor attitudes and instructional practices.

We obtained a response rate of $\sim 14 \%$, which is low compared with the response rates for interview studies with similar recruitment methods (Bush et al., 2015). This low response rate may be due to the controversial nature of the topic, which means that we may have a self-selection issue that may bias the results (Rosenthal and Rosnow, 1975; Brownell et al., 2013). We acknowledge that it could be possible that the pool of interviewees who were willing to talk about their instructional practices are not necessarily reflective of the larger population of instructors, so our findings should be interpreted cautiously (Shortlidge et al., 2016). For instance, $34 \%$ of our participants said that they identified with a religious group, while previous data indicate the rate of religiosity among biology faculty to be around $25 \%$ (Ecklund and Scheitle, 2007), which could indicate a small response bias from religious instructors. However, while our results may represent a specific population's responses, the diversity of viewpoints exhibited during the interviews gives us confidence that we were able to elicit interviews from faculty with different opinions on the topic.

These were self-reports of instructional practices and not observational data. Factors that influence the way individuals self-report, such as social desirability bias, could have influenced these results (Edwards, 1957), and some of the instructors' experiences and perceptions may not be accurately represented. However, this is a limitation of most interview studies, which are often seen as a first step in exploring a new research area in order to subsequently inform more systematic and observational research (Glesne and Peshkin, 1992).
We relied on the interviewees' own definitions of acceptance of evolution, understanding of evolution, and religious beliefs. While this was intentional because we were interested in instructor perspectives, which are dependent on their own definitions, we acknowledge that an important area of future research in evolution education is to come to consensus on these definitions. The published literature on student acceptance of evolution is conflated with multiple definitions and interpretations (Cobern, 1994; Smith, 2009; Smith et al., 1995; Southerland et al., 2001; Sinatra et al., 2003), making this an area ripe for future investigation. We can also begin to explore differences among different religious traditions. Similar to how the term "underrepresented minority" refers to multiple groups of people with unique social identities and experiences, by referring to "religious beliefs" we are not taking into account the differences among those belief systems. Although this is not often done currently, it is important for evolution education researchers to begin to disaggregate students by their religious denominations and the saliency of their religious beliefs.

Finally, some of the instructors in our study were teaching whole semester-long evolution courses, while some were teaching evolution lessons as part of a biology course. This may mean that our interpretations could change if we interviewed only instructors who were teaching semester-long evolution courses. For instance, instructors may be less likely to include a discussion of religion in a 1-wk lesson on evolution than during a whole semester on evolution. However, we did not see any patterns based on the type of course for our study.

\section{CONCLUSION}

To our knowledge, this is the first study to document the attitudes and self-reported instructional practices of college biology instructors about discussing religion in relation to evolution in biology classes. We found that the majority of instructors do not think that it is their goal to help students in their classes accept evolution, that they largely avoid the topic of religion when teaching evolution, and that there is a wide range of barriers that hinder them discussing religion in relation to evolution with their students. These data reinforce the need for a consensus on whether a goal of evolution education should be student acceptance of evolution, which includes a more specific delineation of the definition of acceptance of evolution. Further, it also brings awareness to the potential barriers that instructors may perceive when making decisions about whether to engage with religious students about religion and evolution. We hope that this study will be useful as a reference for instructors as they make their own decisions about how to engage with religious students when teaching about evolution.

\section{ACKNOWLEDGMENTS}

We acknowledge an NSF grant awarded to Sarah Brem for support of this project (0910115) and an NSF Fellowship (DGE-1311230) for graduate student support during this project. We thank Sarah Brem, Erin Shortlidge, and Samantha Belcher for their contributions to the project and Mary Pat Wenderoth, Gale Sinatra, John Lynch, Karin 
Ellison, Sarah Eddy, Mandy Smith, and the Biology Education Research Lab at Arizona State University for their helpful comments and feedback.

\section{REFERENCES}

Abraham JK, Perez KE, Downey N, Herron JC, Meir E (2012). Short lesson plan associated with increased acceptance of evolutionary theory and potential change in three alternate conceptions of macroevolution in undergraduate students. CBE Life Sci Educ 11, 152-164.

Allmon WD (2011). Why don't people think evolution is true? Implications for teaching, in and out of the classroom. Evol Educ Outreach 4, 648-665.

Alters B (1997). Should student belief of evolution be a goal? Rep Nat Cent Sci Educ 17(1), 15-16.

Alters BJ, Nelson CE (2002). Perspective: teaching evolution in higher education. Evolution 56, 1891-1901.

American Association for the Advancement of Science (2011). Vision and Change in Undergraduate Biology Education: A Call to Action, Washington, DC.

Arizona State University (2013). Enrollment Summary: Institutional Analysis. http://uoia.asu.edu/enrollment-summary (accessed 2 February 2016).

Baker JO (2013). Acceptance of evolution and support for teaching creationism in public schools: the conditional impact of educational attainment. J Sci Study Relig 52, 216-228.

Bangera G, Brownell SE (2014). Course-based undergraduate research experiences can make scientific research more inclusive. CBE Life Sci Educ 13, 602-606.

Barnes ME, Elser J, Brownell SE (2017). Two-week evolution module reduces perceived conflict between evolution and religion for religious and non-religious students. Am Biol Teach (in press).

Bishop BA, Anderson CW (1990). Student conceptions of natural selection and its role in evolution. J Res Sci Teach 27, 415-427.

Brickhouse NW, Dagher ZR, Letts WJ IV, Shipman HL (2000). Diversity of students' views about evidence, theory, and the interface between science and religion in an astronomy course. J Res Sci Teach 37, 340-362.

Brownell SE, Freeman S, Wenderoth MP, Crowe AJ (2014). BioCore Guide: a tool for interpreting the core concepts of Vision and Change for biology majors. CBE Life Sci Educ 13, 200-211.

Brownell SE, Kloser MJ, Fukami T, Shavelson RJ (2013). Context matters: volunteer bias, small sample size, and the value of comparison groups in the assessment of research-based undergraduate introductory biology lab courses. J Microbiol Biol Educ 14, 176

Bush SD, Pelaez NJ, Rudd JA, Stevens MT, Tanner KD, Williams KS (2015). Misalignments: challenges in cultivating science faculty with education specialties in your department. BioScience 65, 81-89.

Clough MP (1994). Diminish students' resistance to biological evolution. Am Biol Teach 56, 409-415.

CNN (2005). Arizona: Presidential Voting History. www.cnn.com/ ELECTION/2004/pages/pre/AZ/history.html (25 January 2016).

Cobern B (2004). Apples and oranges: a rejoinder to Smith and Siegel. Sci Educ 13, 583-589.

Cobern WW (1994). Comments and criticism. Point: belief, understanding, and the teaching of evolution. J Res Sci Teach 31, 583-590.

Collins FS (2006). The Language of God: A Scientist Presents Evidence for Belief, New York: Simon and Schuster.
Dagher ZR, BouJaoude S (1997). Scientific views and religious beliefs of college students: the case of biological evolution. J Res Sci Teach 34, 429-445.

Dobzhansky T (1973). Nothing in biology makes sense except in the light of evolution. Am Biol Teach 35, 125-129.

Ecklund EH, Scheitle CP (2007). Religion among academic scientists: distinctions, disciplines, and demographics. Soc Probl 54, 289-307.

Eddy SL, Brownell SE, Thummaphan P, Lan MC, Wenderoth MP (2015). Caution, student experience may vary: social identities impact a student's experience in peer discussions. CBE Life Sci Educ 14(4), ar45.

Eddy SL, Brownell SE, Wenderoth MP (2014). Gender gaps in achievement and participation in multiple introductory biology classrooms. CBE Life Sci Educ 13, 478-492.

Edwards AL (1957). The Social Desirability Variable in Personality Assessment and Research, Fort Worth, TX: Dryden.

Espinosa A, Guillermo C (2009). Acceptance of evolution increases with student academic level: a comparison between a secular and a religious college. Evol Educ Outreach 2, 655-675.

Evans EM (2001). Cognitive and contextual factors in the emergence of diverse belief systems: creation versus evolution. Cogn Psychol $42,217-266$.

Eve RA, Losh SC, Nzekwe B (2010). Lessons from the social psychology of evolution warfare: good science alone is not enough. Evol Educ Outreach 3, 183-192.

Forbes (2014). Northern Arizona University. www.forbes.com/ colleges/northern-arizona-university (accessed 2 February 2016)

Gallup (2009). State of the States: Political Party Affiliation. www .gallup.com/poll/114016/State-States-Political-Party-Affiliation .aspx (accessed 25 January 2016).

Gervais WM (2015). Override the controversy: analytic thinking predicts endorsement of evolution. Cognition 142, 312-321.

Glaser BG, Strauss AL (2009). The Discovery of Grounded Theory: Strategies for Qualitative Research, New Brunswick, NJ: Transaction.

Glesne C, Peshkin A (1992). Becoming Qualitative Researchers: An Introduction, White Plains, NY: Longman.

Gould SJ (2002). The Structure of Evolutionary Theory, Cambridge, MA: Harvard University Press.

Graffin GW, Provine WB (2007). Macroscope: evolution, religion and free will. Am Sci 95, 294-297.

Griffith JA, Brem SK (2004). Teaching evolutionary biology: Pressures, stress, and coping. J Res Sci Teach 41, 791-809.

Hallgren KA (2012). Computing inter-rater reliability for observational data: an overview and tutorial. Tutor Quant Methods Psychol $8(1), 23-34$

Heddy BC, Nadelson LS (2012). A global perspective of the variables associated with acceptance of evolution. Evol Educ Outreach $5,412-418$

Heddy BC, Nadelson LS (2013). The variables related to public acceptance of evolution in the United States. Evol Educ Outreach 6, $1-14$.

Hermann RS (2012). Cognitive apartheid: on the manner in which high school students understand evolution without believing in evolution. Evol Educ Outreach 5, 619-628.

Ingram EL, Nelson CE (2006). Relationship between achievement and students' acceptance of evolution or creation in an upper-level evolution course. J Res Sci Teach 43, 7-24.

Krippendorff K (2012). Content Analysis: An Introduction to Its Methodology, Thousand Oaks, CA: Sage Publications.

Landis JR, Koch GG (1977). The measurement of observer agreement for categorical data. Biometrics 33, 159-174. 
Lawson AE, Worsnop WA (1992). Learning about evolution and rejecting a belief in special creation: effects of reflective reasoning skill, prior knowledge, prior belief and religious commitment. J Res Sci Teach 29, 143-166.

Lloyd-Strovas JD, Bernal XE (2012). A review of undergraduate evolution education in U.S. universities: building a unifying framework. Evol Educ Outreach 5, 453-465.

Manwaring KF, Jensen JL, Gill RA, Bybee SM (2015). Influencing highly religious undergraduate perceptions of evolution: Mormons as a case study. Evol Educ Outreach 8, 23.

Maricopa Community Colleges (2012). Demographics: Maricopa Community Colleges. www.maricopa.edu/about-us/quick-facts/ demographics (accessed 2 February 2016).

Mayr E (1982). The Growth of Biological Thought: Diversity, Evolution, and Inheritance, Cambridge, MA: Harvard University Press.

Mead LS, Clarke JB, Forcino F, Graves JLG Jr (2015). Factors influencing minority student decisions to consider a career in evolutionary biology. Evol Educ Outreach 8, 1-11.

Miller JD, Scott EC, Okamoto S (2006). Public acceptance of evolution. Science 313, 765-766.

Miller KR (1999). Finding Darwin's God: A Scientist's Search for Common Ground between God and Evolution, New York: Cliff Street Books, HarperCollins.

Moore R, Kraemer K (2005). The teaching of evolution \& creationism in Minnesota. Am Biol Teach 67, 457-466.

Morse JM (1997). "Perfectly healthy, but dead": the myth of interrater reliability. Qual Health Res 7, 445-447.

Nadelson LS, Hardy KK (2015). Trust in science and scientists and the acceptance of evolution. Evol Educ Outreach 8, 9.

Nadelson LS, Sinatra GM (2010). Shifting acceptance of evolution: promising evidence of the influence of the Understanding Evolution website. The Researcher 23(1), 13-29.

Nadelson LS, Southerland SA (2010). Examining the interaction of acceptance and understanding: how does the relationship change with a focus on macroevolution? Evol Educ Outreach 3(1), 82-88.

Nadelson LS, Southerland S (2012). A more fine-grained measure of students' acceptance of evolution: development of the Inventory of Student Evolution Acceptance-I-SEA. Int J Sci Educ 34, 1637-1666.

National Academy of Sciences (NAS) (1998). Teaching about Evolution and the Nature of Science. Www.nap.edu/openbook.php? record_id=5787\&page=R1 (accessed 16 March 2015).

NAS (2008). Science, Evolution, and Creationism www.nap.edu /openbook.php?record_id=11876 (accessed 16 March 2015).

National Center for Education Statistics (2013). Digest of Education Statistics, 2013. https:/ /nces.ed.gov/programs/digest/d13/tables / dt13_308.10.asp?current =yes (accessed October 19, 2015).

National Center for Science and Engineering Statistics (2011). Doctorate Recipients from U.S. Universities: 2011, Special Report NSF 13-301, Arlington, VA. www.nsf.gov/statistics/sed (accessed 2 February 2016).

Nehm RH, Kim SY, Sheppard K (2009). Academic preparation in biology and advocacy for teaching evolution: biology versus non-biology teachers. Sci Educ 93, 1122-1146.

Nehm RH, Reilly L (2007). Biology majors' knowledge and misconceptions of natural selection. BioScience 57, 263-272.

Nesse RM (1996). Why We Get Sick: The New Science of Darwinian Medicine, New York: Vintage.

Nesse RM, Bergstrom CT, Ellison PT, Flier JS, Gluckman P, Govindaraju DR, Niethammerg D, Omennh GS, Perlmani RL, Schwartz MD, et al. (2010). Making evolutionary biology a basic science for medicine. Proc Natl Acad Sci USA 107(suppl 1), 1800-1807.
Newport F (2014, June). In U.S., 42\% Believe Creationist View of Human Origins. June www.gallup.com/poll/170822/believe -creationist-view-human-origins.aspx (accessed 13 March 2015).

Numbers RL (2006). The Creationists: From Scientific Creationism to Intelligent Design, Cambridge, MA: Harvard University Press.

Pew Research Center (2015). America's Changing Religious Landscape. www.pewforum.org/2015/05/12/americas-changing -religious-landscape (accessed 19 October 2015).

Rachels J (1990). Created from Animals: The Moral Implications of Darwinism, New York: Oxford University Press.

Rice JW, Clough MP, Olson JK, Adams DC, Colbert JT (2015). University faculty and their knowledge and acceptance of biological evolution. Evol Educ Outreach 8, 8.

Rice JW, Olson JK, Colbert JT (2010). University evolution education: the effect of evolution instruction on biology majors' content knowledge, attitude toward evolution, and theistic position. Evol Educ Outreach 4, 137-144.

Rissler LJ, Duncan SI, Caruso NM (2014). The relative importance of religion and education on university students' views of evolution in the Deep South and state science standards across the United States. Evol Educ Outreach 7, 24.

Rosenthal R, Rosnow RL (1975). The Volunteer Subject. http:/ / doi .apa.org/psycinfo/1975-20053-000 (accessed 19 October 2015).

Roth W (1997). The interaction of students' scientific and religious discourses: two case studies. Int J Sci Educ 19, 125-146.

Rutledge ML, Sadler KC (2011). University students' acceptance of biological theories-is evolution really different? J Coll Sci Teach 41,38 .

Scott E (2014). Equipping scientists to better understand and converse with religious communities: NCSE. Presented at the American Association for the Advancement of Science, Chicago, 16 February 2014. http:/ / ncse.com/node/15049.

Scott EC (2005). Evolution vs. Creationism: An Introduction, Berkeley: University of California Press.

Seymour E (2000). Talking about Leaving: Why Undergraduates Leave the Sciences, Boulder, CO: Westview.

Shortlidge EE, Bangera G, Brownell SE (2016). Faculty Perspectives on developing and teaching course-based undergraduate research experiences. BioScience 66, 54-62.

Shtulman A, Calabi P (2008). Learning, understanding, and acceptance: the case of evolution. In: Proceedings of the 30th Annual Conference of the Cognitive Science Society, New York: Routledge, 235-240.

Sinatra GM, Brem SK, Evans EM (2008). Changing minds? implications of conceptual change for teaching and learning about biological evolution. Evol Educ Outreach 1, 189-195.

Sinatra GM, Southerland SA, McConaughy F, Demastes JW (2003). Intentions and beliefs in students' understanding and acceptance of biological evolution. J Res Sci Teach 40, 510-528.

Sinclair A, Pendarvis MP, Baldwin B (1997). The relationship between college zoology students' beliefs about evolutionary theory and religion. J Res Dev Educ 30, 118-125.

Singer SR, Nielsen NR, Schweingruber HA (eds.) (2012). Discipline-Based Education Research: Understanding and Improving Learning in Undergraduate Science and Engineering, Washington, DC: National Academies Press.

Smith MU (1994). Counterpoint: belief, understanding, and the teaching of evolution. J Res Sci Teach 31, 591-597.

Smith MU (2009). Current status of research in teaching and learning evolution: II. pedagogical issues. Sci Educ 19, 539-571.

Smith MU, Siegel H, McInerney JD (1995). Foundational issues in evolution education. Sci Educ 4, 23-46. 
Southerland SA, Scharmann LC (2013). Acknowledging the religious beliefs students bring into the science classroom: using the bounded nature of science. Theory Pract 52, 59-65.

Southerland SA, Sinatra GM, Matthews MR (2001). Belief, knowledge, and science education. Educ Psychol Rev 13, 325-351.

Tanner KD (2013). Structure matters: twenty-one teaching strategies to promote student engagement and cultivate classroom equity. CBE Life Sci Educ 12, 322-331.

University of Arizona (2014). IR at University Analytics and Institutional Research. http:/ / oirps.arizona.edu/studentdemographics .asp (accessed 2 February 2016).
Verhey SD (2005). The effect of engaging prior learning on student attitudes toward creationism and evolution. BioScience 55, 996-1003.

Wilbur N, Withers M (2015). Teaching practices and views of evolution instructors at post-secondary institutions. Evol Educ Outreach 8,12 .

Wiles JR, Alters B (2011). Effects of an educational experience incorporating an inventory of factors potentially influencing student acceptance of biological evolution. Int J Sci Educ 33, 2559-2585.

Winslow MW, Staver JR, Scharmann LC (2011). Evolution and personal religious belief: Christian university biology-related majors' search for reconciliation. J Res Sci Teach 48, 1026-1049. 